\title{
КОМПЕНСАЦІЯ УПУЩЕНОЇ ВИГОДИ: СУТНІСТЬ ТА ЗАСТОСУВАННЯ В МІЖНАРОДНІЙ СУДОВІЙ ПРАКТИЦІ
}

Грабович T. А.

\begin{abstract}
У статті висвітлено питання компенсації упущеної вигоди на підставі вивчення сучасної міжнародної судової практики. Визначено, що в разі неможливості та незастосовності реституції, з метою забезпечення повного компенсування завданої шкоди засто-
\end{abstract} совується компенсація. Установлено, що в пункті 2 статmi 36 Статей про відповідальність держав за міжнародно-протиправні 2001 року передбачається доречність у деяких випадках компенсації упущеної вигоди. Установлено наявність трьох видів упущеної вигоди, як-от: упущена вигода від майна, що приносить дохід, за період, коли не було перешкод для використання права власності, на відміну від тимчасової втрати права користування (ця категорія пов'язана з позовами про стягнення упущеної вигоди через тимчасову втрату права користування і використання активу, що приносить дохід); упущена вигода від майна, що приносить дохід, з дати позбавлення права власності до дати винесення рішення про компенсацію (ия категорія претензій стосується неправомірного вилучення майна, що приносить дохід); упущена майбутня вигода, коли присуджується відшкодування прибутку, очікуваного після дати ухвалення рішення про компенсацію (така категорія претензій щодо упущеної вигоди виникає в основному в контексті концесій). 3'ясовано, якщо упущена вигода повинна присуджуватися, то немає підстав для присудження відсотків із капіталу, що приносить прибуток за той же період часу, виходячи з того, що дана сума капіталу не може водночас приносити відсоток і прибуток. Доведено, що упущена вигода в низці справ була виключена на тій підставі, що вона не мала достатнього підтвердження як інтерес, що юридично захищається. Зроблено висновок, що на практиці упущена вигода присуджується порівняно з компенсацією за нараховані збитки не дуже часто, що зумовлено тим, що судові органи не схильні надавати компенсацію щодо вимог, які мають гіпотетичні елементи. 3 метою досягнення справедливого та прийнятного для сторін врегулювання спору для присудження упущеної вигоди варто використовувати гнучкий підхід, з урахуванням сформованих у міжнародній судовій практиці підходів та методів щодо встановлення компенсації.

(с) Грабович Т. А., 2020
Ключові слова: компенсація, упущена вигода, Комісія міжнародного права ОOH, Cmammi про відnовідальність держав.

Grabovich T. A. Loss of profits: essence and applications in international judicial practice

The article covers the issue of compensation for loss of profits based on the study of modern doctrine and practice of international law. It is determined that in cases of impossibility and inapplicability of restitution, in order to ensure full reparation for damage, compensation is applied. It is established that paragraph 2 of Article 36 of the Articles on the Responsibility of States for Internationally Wrongful acts 2001 provides for the appropriateness in some cases of compensation for loss of profits. It is established that there are three types of loss of profits: lost profits from income-producing property during a period when there has been no interference with title as distinct from temporary loss of use (this category involves claims for loss of profits due to the temporary loss of use and enjoyment of the income-producing asset); lost profits from income-producing property between the date of taking of title and adjudication (this category of claims relates to the unlawful taking of income-producing property); lost future profits in which profits anticipated after the date of adjudication are awarded (this category of claims for lost profits arises mainly in the context of concessions). It was found that if the loss of profits is to be awarded, it is inappropriate to award interest on the profit-earning capital over the same period of time, simply because the capital sum cannot be simultaneously earning interest and generating profits. The essential aim is to avoid double recovery while ensuring full reparation. It has been established that the lost benefit in a number of cases was excluded on the ground that it was not sufficiently substantiated as a legally protected interest. It is concluded that, in practice, lost profits are awarded less often than compensation for accrued damages, due in part to the fact that judicial authorities are reluctant to provide compensation for claims that have certain hypothetical elements. In order to achieve a fair and acceptable settlement of the dispute, a flexible approach should be used to award lost profits, taking into account the approaches and methods of establishing compensation in international case law.

Key words: compensation, lost profits, International Law Commission, Articles on State Responsibility. 
Постановка проблеми та іï актуальність. Поняття «компенсація» $\epsilon$ дуже широким і має різні значення. У загальному розумінні компенсація - "еmenda", $\epsilon$ те, що передається потерпілому в результаті правопорушення [1, с. 216]. Історично основною сферою застосування компенсації був дипломатичний захист за шкоду, завдану іноземцям. Значна практика була створена змішаними комісіями з позовних вимог, арбітражними судами й іншими судовими або квазісудовими органами, зокрема щодо оцінки особистої шкоди та майнових вимог. Нині компенсація відіграє важливу роль у міжнародних інвестиційних спорах, у міжнародному праві прав людини. Випадки компенсації за пряму шкоду, завдану державою іншій державі, тобто без участі індивідів, зокрема громадян потерпілої держави, $\epsilon$ рідкими [2, c. 499-500].

Загалом компенсація означає здійснення відповідного платежу за певну втрату чи шкоду, завдану певному суб'єкту. У міжнародному праві термін «компенсація» має різні вживання: по-перше, компенсація означає форму відшкодування у праві міжнародної відповідальності, що відмінна від реституції та сатисфакції; по-друге, у контексті відповідальності за правомірні діяння компенсація означає виплату грошової суми як відшкодування за діяння, не заборонені міжнародним правом; по-третє, своєрідне розуміння компенсації можна знайти в інших галузях міжнародного права. Наприклад, у праві СОТ передбачається особливий вид «добровільної компенсації», на відміну від компенсації у праві про відповідальність держав [2, с. 499]. С. Віттіч уважає, що компенсація в контексті права міжнародної відповідальності держав $\epsilon$ гнучким засобом, що стимулює продуктивну економічну діяльність через зниження або усунення певних ризиків. Компенсація може посилити відповідальність та зменшити ризик, тим самим сприяє продуктивним фінансовим операціям [3, с. 610]. Зважаючи на роль компенсації

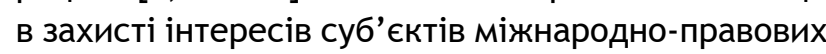
відносин, дослідження іï застосування, зокрема компенсації упущеної вигоди, має велике практичне та теоретичне значення.

Аналіз останніх досліджень і публікацій. Відповідальність держав за міжнародно-протиправні діяння як багатогранна проблематика була предметом дослідження таких учених, як: В.Ф. Антипенко, Я. Броунлі, В.А. Василенко, Д. Джінкс, О.В. Задорожній, А. Зайберт-Фор, І.І. Лукашук, Б. Конфорті, Дж. Кроуфорд, В.А. Мазов, С. Оллесон, М. Сассолі, М.О. Ушаков, М.Х. Фарукшин та інші. Водночас компенсації як формі відшкодування збитків, зокрема проблемі компенсації упущеної вигоди, не приділено достатньої уваги, що зумовлює необхідність дослідження цього питання.

Мета статті - дослідити питання компенсації упущеної вигоди на підставі вивчення сучасної міжнародної судової практики.

Виклад основного матеріалу. Ст. 36 Статей про відповідальність держав 2001 р. стосується компенсації за шкоду, завдану внаслідок міжнародно-протиправного діяння, тією мірою, якою така шкода не компенсується реституцією. Поняття «шкода» включає будь-яку шкоду, матеріальну або моральну. У п. 2 ст. 36 відзначено, що компенсація охоплює будь-яку обчислювану у фінансовому вираженні шкоду, зокрема й упущену вигоду, наскільки вона встановлена в даному разі. Застереження «обчислювану у фінансовому вираженні» спрямоване на те, щоб виключити компенсацію за те, що іноді називають «моральною шкодою» державі, тобто образу чи шкоду, завдані внаслідок порушення прав, які не пов'язані з фактичною шкодою майну або людям: це поняття $\epsilon$ предметом сатисфакції [4, с. 119].

У п. 2 ст. 36 визнається, що іноді може бути доречна компенсація упущеної вигоди. Міжнародні трибунали включають присудження компенсації за втрачену вигоду в оцінку розміру компенсації [4, с. 125]. У справі “Crystallex International Corporation v. Bolivarian Republic of Venezuela" (2016 р.) арбітраж зазначив, що «у статтях КмП визнається, що в певних випадках може бути доречна компенсація упущеної вигоди» [5, п. 873]. Упущена вигода відіграла свою роль у справі “Factory at Chorzów”, коли ППмП постановила, що відшкодування збитку потерпілій стороні має бути надано не в сумі вартості майна в тому вигляді, у якому воно було в момент експропріації, а в сумі вартості на момент відшкодування [4, с. 126].

У своєму рішенні у справі "Sempra Energy International v. Argentine Republic" (2007 р.) арбітраж послався на вимогу п. 2 ст. 36 як на таку, що відбиває «належний стандарт відшкодування згідно з міжнародним правом за відсутності реституції або узгодженого переукладання контрактів або інших заходів виправлення становища» [6, п. 401]. У справі “Archer Daniels Midland Company and Tate \& Lyle Ingredients Americas, Inc. v. Мехісо" (2007р.) арбітраж відзначив, що «компенсація охоплює як понесені збитки (damnum emergens), так і упущену вигоду (lucrum cessans). Будь-яка безпосередня шкода підлягає компенса- 
ції. Крім того, у п. 2 ст. 36 визнається, що в окремих випадках компенсація упущеної вигоди може бути доречна, щоб відобразити норму, яка застосовується відповідно до міжнародного звичаєвого права» [7, п. 281].

На практиці упущена вигода присуджується не так часто, як компенсація за нараховані збитки. Судові органи не схильні надавати компенсацію за вимогами, що явно мають гіпотетичні елементи. Упущена вигода в низці справ була виключена на тій підставі, що вона не мала належного підтвердження як інтерес, що юридично захищається. Крім того, вимоги щодо упущеної вигоди підпорядковуються звичайному комплексу обмежень щодо компенсування шкоди, як-от причинно-наслідковий зв'язок, віддаленість, вимоги доведеності і принципи бухгалтерського обліку, які покликані знизити роль гіпотетичних елементів у прогнозованих даних [4, с. 126-127].

У своєму рішенні “LG \& E Energy Corp., LG \& E Capital Corp. , LG \& E International Inc. v. Argentina” (2007 р.) арбітраж застосував ст. 36 Статей про відповідальність держав під час визначення збитків, понесених вкладником. Він зазначив, що «питання, яке арбітраж повинен розглянути, полягає у встановленні «фактичних збитків», понесених вкладником, «у результаті» поведінки Аргентини. Це питання «причинно-наслідкового зв'язку»: що втратив вкладник через протиправні діяння?» [8, п. 45]. У рішенні у справі “Burlington Resources Inc. v. Republic of Ecuador” (2017 р.) арбітраж, з посиланням на ст. 36 Статей про відповідальність держав, визначив, що компанія «Берлінгтон» не довела з належною переконливістю, як того вимагає міжнародне право в разі пред'явлення вимоги про компенсацію упущеної вигоди, що «Берлінгтон» реалізацією свого права на переговори про продовження контракту справді домоглася б продовження контракту, право на яке могло б бути «відчужене» шляхом експропріації [9, п. 278].

У справах "Gemplus S.A. et al. v. The United Mexican States" i "Talsud S.A. v. The United Mexican States” (2010р.) арбітражний трибунал звернув увагу на коментар до п. 2 ст. 36 як на такий, що містить вказівки щодо розгляду якості доказів, необхідних від заявника для підтвердження безпосередньо або побічно його вимоги щодо упущеної вигоди відповідно до міжнародного права, і зазначив, що в коментарі підкреслюється «визначеність, яку у всіх випадках повинен встановити заявник на підставі доказів». Арбітраж вказав на очевидність, що «концепція визначеності $€$ як відносною, так і розумною у своєму застосуванні з урахуванням обставин конкретної справи». Далі арбітраж вказав, що ця концепція «стосується можливих майбутніх подій, а не реальних минулих подій; вона має на увазі визначення не того, що сталося або не сталося в минулому, а того, що могло б статися в майбутньому. Ця процедура в обов'язковому порядку вимагає від Трибуналу визначити, чи трапилися б ці події в майбутньому, і провести їх оцінку у грошовому вираженні для цілей компенсації. Заявник не завжди може з певністю довести, що якась подія могла або не могла статися в майбутньому, водночас Трибунал тільки оцінює ймовірність такої майбутньої події. Отже, йдеться не про підтвердження визначеності як таке, а радше про підтвердження в даних обставинах «достатньої визначеності»» [10, пп. 13-91].

Арбітраж у справі “LG\&E Energy Corp., LG\&E Capital Corp., LG \& E International Inc. v. Argentina” (2007 р.) розглядав питання про втрачену вигоду. Суд заявив, що «у принципі на даному етапі необхідно підкреслити відмінність між збитками, що виникли, та упущеною вигодою. Якщо перше зазвичай арбітражі присуджували, то остання присуджувалася лише тоді, коли «очікуваний потік надходжень отримував досить властивостей, що дозволяють вважати його юридично охоронюваним інтересом досить певного характеру для того, щоб підлягати компенсації». Або, якщо користуватися текстом проєкту статей, «у доведеному обсязі». Це питання «визначеності». Арбітражі неохоче надають компенсацію в задоволення вимог, що містять по суті спекулятивні елементи» [11, п. 51].

У рішенні у справі “Joseph C. Lemire v. Ukraine” (2011 р.) арбітраж, з посиланням на п. 2 ст. 36 як такий, що відображає прийняте розуміння мети компенсації, вказав, що цей пункт містить тільки «теоретичне визначення загального стандарту; безпосередній розрахунок шкоди не може бути абстрактним, він повинен залежати від обставин конкретної справи: він вимагає визначення фінансової методології для оцінки грошової суми, яка, будучи передана інвестору у справі, що розглядається, зумовить економічну вигоду, еквівалентну тій, яку, цілком імовірно, міг би набути інвестор, якби не було порушення з боку держави» $[12$, п. 152]. Трибунал також зазначив, що обов'язок здійснити відшкодування поширюється тільки на випадки, коли така шкода із правового погляду розглядається як наслідок протиправного діяння, що компенсація в разі заяв спекулятивного характеру зазвичай не присуджується [12, п. 245-246]. 
У справі “El Paso Energy International Company v. The Argentine Republic" (2011р.) арбітражний трибунал зазначив, що «посилання на «упущену вигоду» у ст. 36 (2) підтверджує, що цінність майна варто визначати станом на дату, наступну за датою міжнародно-протиправного діяння, за умови, що шкода $\epsilon$ «обчислюваною у фінансовому вираженні», отже, не $\epsilon$ спекулятивною» $[13$, п. 710]. У своєму рішенні щодо компенсації у справі "Ahmadou Sadio Diallo (Republic of Guinea v. Democratic Republic of the Congo)" (2012 p.) Мiжнародний суд ООН відзначив: «Хоча рішення про виплату компенсації у зв'язку з упущеною вигодою неминуче передбачає деяку невизначеність, таке твердження не може мати суто спекулятивний характер» $[14$, п. 49].

КМП ООН вказує на три види упущеної вигоди:

- по-перше, упущена вигода від майна, що приносить дохід, за період, коли не було перешкод для використання права власності, на відміну від тимчасової втрати права користування. Ця категорія пов'язана з позовами про стягнення упущеної вигоди через тимчасову втрату права користування активом і використання активу, що приносить дохід;

- по-друге, упущена вигода від майна, що приносить дохід, з дати позбавлення права власності до дати винесення рішення про компенсацію. Ця категорія претензій стосується неправомірного вилучення майна, що приносить дохід;

- по-третє, упущена майбутня вигода, коли присуджується відшкодування прибутку, очікуваного після дати ухвалення рішення про компенсацію. Така категорія претензій щодо упущеної вигоди виникає в контексті концесій та інших інтересів, що захищаються договорами [4, с. 126-127].

Дж. Кроуфорд виділяє два види втрати прибутку (упущена вигода) [15, с. 522]: прибуток, який передбачалося накопичити до дати судового рішення, та прибуток, який передбачається накопичити після цієї дати. Щодо першого, то «компенсацію можна вимагати у зв'язку із втручанням у право власності позивача, що мало місце у справі про фабрику в Хожуві та в ситуації, коли мала місце тимчасова втрата в користуванні майном, наприклад, у справі “S. D. Myers v. Canada” (2002 р.)” [16, с. 137]. Більш складним $€$ відшкодування збитків стосовно прибутку, отримання якого очікується після дати винесення рішення. Зазвичай така шкода не буде виправданою, оскільки за рішенням суду зазначене майно, що приносить дохід, буде відновлено шляхом реституції або компенсації. Однак претензії щодо майбутньої упущеної вигоди були підтримані в контексті захищених договором інтересів, як-от у справі “Liamco v. Libya” (1977 р.) [17]. Справа була пов'язана з концесійним контрактом, що був укладений LIAMCO для розвідки та видобутку нафти, що мали відбуватися до 1988 р., але сталася націоналізація на початку 1970-х pp. [15, с. 522]. Звичайно, майбутній потік доходів компенсується лише до того часу, коли закінчується юридичне визнання права [4, с. 127].

Варто також наголосити, якщо упущена вигода повинна присуджуватися, то немає підстав для присудження відсотків із капіталу, що приносить прибуток, за той же період часу, адже дана сума капіталу не може водночас приносити відсоток і прибуток. Головна мета полягає в уникненні подвійного відшкодування за одночасного забезпечення цілковитого компенсування [4, с. 127].

Дж. Баркер слушно зауважує, що багато спорів, пов'язаних із завданою шкодою, $\epsilon$ результатом недоліків ухвалення публічних та корпоративних рішень. Завдяки поступальному розвитку національних стандартів і міжнародної доктрини щодо компенсації можна очікувати, що з'являться норми та практика щодо скорочення i врегулювання суперечок між державами і приватними сторонами [3, с. 611]. Варто відзначити, що під час обговорення проєкту ст. 36 Статей про відповідальність 2001 р. схвалені реґламентація компенсації за гнучкою формулою й ідея про те, щоб правила визначення розмірів компенсації формувалися у процесі практики, оскільки детальний посібник із цього питання міг 6 виявитися недостатньо гнучким для врахування всіх обставин [1, с. 227].

Висновки. Держава, що вчинила міжнародно-протиправне діяння, має зобов'язання здійснити відшкодування за наслідки, що випливають із такого діяння. У разі вчинення міжнародно-протиправного діяння передусім постає питання про здійснення реституції (restitutio in integrum та restitutio in pristinum), однак така форма відшкодування часто виявляється неможливою (через матеріальну неможливість або непропорційність) або не забезпечує цілковитого відшкодування завданих збитків, або держава, яка їх зазнала, обирає іншу форму відшкодування. У разі неможливості та незастосовності реституції з метою забезпечення цілковитого відшкодування завданих збитків застосовується компенсація.

Питання щодо упущеної вигоди під час установлення компенсації $\epsilon$ предметом розгляду різноманітних міжнародних судових, арбітражних і адміністративних органів: Міжнародного суду $\mathrm{OOH}$, Міжнародного центру з урегулювання інвес- 
тиційних спорів, Компенсаційної комісії ООН, Міжнародного трибуналу з морського права, Європейського суду з прав людини, Міжамериканського суду з прав людини тощо, поряд із міждержавними справами щодо територіальних претензій, індивідуальними позовами про завдану матеріальну та моральну шкоду, борговими вимогами, позовами щодо бізнес-активів тощо.

На практиці упущена вигода присуджується, якщо порівняти з компенсацією за нараховані збитки, не дуже часто, що зумовлено тим, що судові органи не схильні надавати компенсацію щодо вимог, які мають гіпотетичні елементи. 3 метою досягнення справедливого та прийнятного для сторін урегулювання спору для присудження упущеної вигоди варто використовувати гнучкий підхід, з урахуванням сформованих у міжнародній судовій практиці підходів та методів щодо встановлення компенсації.

\section{Література}

1. Лукашук И.И. Право международной ответственности. Москва : Волтерс Клувер, 2004. 432 с.

2. Wittich S. Compensation. Max Planck Encyclopedia of Public International Law. 2008. Vol. II. P. 499-508.

3. Barker J. The Different Forms of Reparation : Compensation. The Law of International Responsibility / J. Crawford, A. Pellet, S. Ollesson (eds). 2010. P. 599-611.

4. Проекты статей об ответственности государств за международно-противоправные деяния с комментариями к ним. Ежегодник Комиссии международного права. 2001. Т. ІІ. Ч. 2. С. 32-174.

5. ICSID. Crystallex International Corporation v. Bolivarian Republic of Venezuela. Case № ARB(AF)/11/2. Award. 4 April 2016.
6. ICSID. Sempra Energy International v. Argentine Republic. Case № ARB/02/16. Award. 28 September 2007.

7. ICSID. Archer Daniels Midland Company and Tate \& Lyle Ingredients Americas, Inc. v. The United Mexican States. Case № ARB(AF)/04/05. Award. 21 November 2007.

8. ICSID. LG\&E Energy Corp., LG\&E Capital Corp., LG\&E International Inc. v. Argentine Republic, Case № ARB/02/1. Award. 25 July 2007.

9. ICSID. Burlington Resources Inc. v. Republic of Ecuador. Case № ARB/08/5. Decision on Reconsideration and Award. 7 February 2017.

10. ICSID. Gemplus S.A. et al. v. The United Mexican States and Talsud S.A. v. The United Mexican States. Case № ARB(AF)/04/3. Award. 16 June 162010.

11. ICSID. LG\&E Energy Corp. LG\&E Capital Corp. LG \& E International Inc. v. Argentine Republic. Case № ARB/02/1. Award. 25 July 2007.

12. ICSID. Joseph C. Lemire v. Ukraine. Case № ARB/06/18. Award. 28 March 2011.

13. ICSID. El Paso Energy International Company v. The Argentine Republic. Case № ARB/03/15. Award. 31 October 2011.

14. ICJ. Ahmadou Sadio Diallo (Republic of Guinea v. Democratic Republic of the Congo). Judgment of 19 June 2012.

15. Crawford J. State Responsibility : The General Part. Cambridge : Cambridge University Press, 2013. $912 \mathrm{p}$.

16. ICSID. S.D. Myers Inc. v. Canada. Second Partial Award. 21 October 2002.

17. Libyan American Oil Company v. Libya. 12 April 1977. 62 ILR 140.

Грабович T. А., кандидат юридичних наук 